\title{
THE CULTURE AND IDENTITY PRESERVATION IN THE HUNGARIAN COMMUNITIES
}

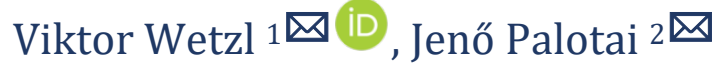 \\ 1, 2 PhD student, University of Pécs, Faculty of Sciences, Earth Sciences Doctoral School, Hungary
}

DOI: https://doi.org/10.29121/granthaalayah.v9.i1.2021.2921

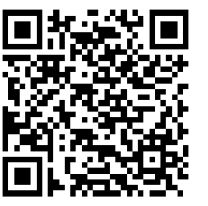

Article Type: Research Article

Article Citation: Viktor Wetzl, and Jenő Palotai. (2021). THE CULTURE AND IDENTITY PRESERVATION IN THE HUNGARIAN COMMUNITIES. International Journal of Research GRANTHAALAYAH, 9(1), 257-270. https://doi.org/10.29121/granthaa layah.v9.i1.2021.2921

Received Date: 20 December 2020

Accepted Date: 31 January 2021

Keywords:

Hungarian Diaspora

Identity Preservation

Language Education

Hungarian School

\begin{abstract}
The study aims to give a thorough analysis on the Hungarian language education for the Hungarian Diaspora. After reviewing the relevant literature, the authors intend to survey the overall situation, geographical allocation, identity preserving and community organising activity of the cross-border Hungarians with a special focus on the history and present trends of the Hungarian language education for the diaspora. As case studies we analyse and compare Hungarian schools from each related continent with a considerable Hungarian diaspora (Australia, North America and Africa) based on their language education and identity preserving activities.
\end{abstract}

\section{INTRODUCTION}

The aim of our research is to analyse the Hungarian identity preservation by introducing the Hungarian language education in the diaspora. The objective to analyse this topic was formulated in the authors during the data collecting field trips at the different Hungarian Diasporas. The collected primary data were elaborated with the help of the empirical experiences and the international and domestic literature. During the research process three Hungarian schools were chosen with geographical sampling focusing on their Hungarian language education together with the motivations and attitudes of the students. We also compare the identity preserving activities, education methods, output requirements and the motivations of the students of these schools with which we believe the reader receives a comprehensive picture of the identity preserving activities at three different continents and their peculiarities.

\section{MATERIALS AND METHODS}

Besides the survey of the related literature and statistical data the basic method for the research was interviewing. Data collection by interviews is a widely accepted method in sociology and at those subfields of linguistics where attitudes, stereotypes and ideologies are surveyed (Kvale, 2005; Feischmidt, 2007). The subjects

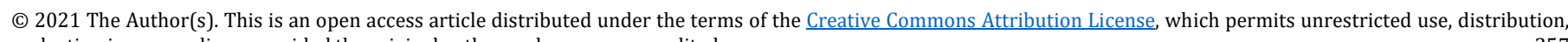
and reproduction in any medium, provided the original author and source are credited. 
of the interviews were the higher leaders of the institutes (directors, education leaders) with decision making powers, the teachers and the students and their parents.

During the selection process of the data providers and during the analysis we did not bear in mind the sociological representativeness but we aimed to collect a coherent text about the language education and identity preserving aspects of the Hungarians living in the Diaspora with which we can receive a comprehensive picture about the subject of our research. As a qualitative collection of data, we are unable to totalize statistically the experiences of all the teachers and students or all the schools involved in identity preserving, but we believe that due to the depth of the interviews our method can provide a thorough and detailed knowledge about the research topic. We chose the three schools in the three continents with a geographical sampling technique where in one case we carried out research field work as well (Cleveland, USA, between 10-10-2017 - 30-10-2017). In all the other cases the interviews were made during personal meetings in Hungary or online. The interviews were carried out with the help and support of the Pallas Athéné Foundations, the Tempus Public Foundation and the Diaspora Project of the University of Pécs. During the research altogether 10 interviews were carried out in the different schools with the responsible leaders with the method of semi-structured deep interviews.

\section{RESULTS}

\subsection{THE POLITICAL GEOGRAPHICAL SIGNIFICANCE OF LANGUAGE AND CULTURE}

The language is the element of the explicit culture (Jarjabka 2012). "Culture is an aggregation of deeply rooted values and assumptions shared by a certain group of people which determines the relations between the members and between the people and the natural environment". (Maznevski - Peterson 1998, 65. in. Jarjabka 2012 , 13. translated by the authors). The basics for national identity is provided by the language, the common history, the values of the group, the common genesis myth, the common heroes, the great tragedies and achievements, the symbolic institutions and places, which are preconditions for the national consciousness as the ideology connecting the nation (group of people) with the geographical space (homeland) (Taylor et. al, 2000). So, in this train of thought culture, identity and space are connected with each other and culture will have a geographical role connecting the nation with the space with an indirect importance. Nevertheless, this interaction is true vice versa as well, so the certain favoured elements of space all actuate the identity and become its very important building blocks (Nora, 2003).

After different migration cycles and the Treaty of Trianon in a political geographical sense the Hungarian nation split into several groups with different situations so we can distinguish majority-minority relations, according to which there is a position of nation and culture in Hungary and in the states where Hungarians live in minority as well. During the Hungarian migration we can differentiate several migration periods conducing to the present number of Hungarians outside the country (Gazsó, 2016).

The $1^{\text {st }}$ period was experienced before 1849 where the migrants left the country mainly because of adventurousness and with the aim of enrichment. The $2^{\text {nd }}$ period started after 1849 until the Compromise in 1867, when mainly the privates left the country because they feared from the punishment. The $3^{\text {rd }}$ period started after the Compromise until the end of the $1^{\text {st }}$ World War, where first the peasants who lost their farms and later those with the aim of enrichment migrated to foreign countries, characteristically to North America (Kuncz, 1997; Gazsó, 2016).

The $4^{\text {th }}$ period started after the 1 st World War until the end of the end of the $2^{\text {nd }}$ World War, when the migration due to economic reasons still lasted and respectively the population of the annexed areas left their new countries and started their new life in the western world or in Australia. During the $4^{\text {th }}$ migration period, because of the political persecution in the 1930s, numerous Hungarian citizens left the country who settled down mainly in North America, United Kingdom or in Australia (Kuncz, 1997; Gazsó, 2016).

The $5^{\text {th }}$ period started after the $2^{\text {nd }}$ World War lasting until the 1956 Revolution. In the beginning of this period characteristically those citizens left the country who were either running from the war punishment or there were also many settling down in Israel after its establishment in 1948. Besides this the altered Hungarian political regime after the $2^{\text {nd }}$ World War also stimulated the migration towards the west.

The $6^{\text {th }}$ period started after the 1956 Revolution when characteristically political refuges left Hungary but they also defected because of a better existence to the western countries. This process lasted until 1989. 
Viktor Wetzl, and Jenő Palotai

The $7^{\text {th }}$ period started from the change of the regime up till nowadays where similar to some earlier periods (the $1^{\text {st }}$ and the 3rd) typically people decide to migrate because of the better financial opportunities (Kuncz, 1997; Gazsó, 2016).

Due to the different migration periods and the change of the border through history we can study Hungarians living in block, sporadically and in diaspora. To live the experience of the culture in a minority position is characterised by a duality, since one stands under the influence of two factors simultaneously actuating each other. The cross border Hungarian culture is an integral part of the Hungarian national culture, at the same time it is also a coexisting culture, so it is permanently interfering with the local cultures (Vers et al., 2017). Nevertheless, due to migration our world becomes a global melting pot (Csapó et. al., 2007). The relationship will not be ceased with the deportations and changes of border but a complex relation system will evolve. Dual citizenship, dual cultural badinage, multi-identities, multi loyalty and community life with a network structure will be the typical forms. Due to this the significance of the organisations (and especially the churches, religious organisations) with stable structure and basis will be strengthened (Keményfi, 2011).

\subsection{THE ENDANGERMENT OF THE HUNGARIAN LANGUAGE AND THE PROCESS OF LANGUAGE SHIFT AT THE CROSS-BORDER HUNGARIANS}

Language shift is a global phenomenon. From history we have many examples that a folk or a smaller group of folk leaves behind its everyday language and will use another language (for instance the Bulgarian language shift from the $9^{\text {th }}$ century) (Gal, 1991). The majority of the global population lives in a dual or multilingual community (Borbély, 2001) which can formulate from one or multilingualism. "The bilingual situation can develop to monolingual, trilingual or stable bilingual" (Tabouret-Keller 1968, 108; Borbély, 2001). "Language shift is a phenomenon existing from the times when languages got in touch with each other" (Grosjean 1982, 102.). The local or even the global social, economic, political etc. processes and the narrower and broader language environmental context have a great impact in every age on the life of the languages and their talking communities (Bartha, 2003).

In the last decades the globalisation, the continuous migration, the break-up of the Soviet Union and Yugoslavia, the appearance of new or re-contextualized national or ethnic identities and national languages, the broadening of the European Community radically reshaped the scientific and everyday thinking about the role and future of multilingualism and cultural diversity and further on had an impact on the formation of the new forms of sociallingual relations among the different language groups living within the same state (Bartha, 2003). The countries going against these changes at the same time try to counteract the decreasing capacity of the state in monitoring the economic, cultural and social institutions and on the other hand they intend to match to the international legal requirements created for the modern democracies stating that for multiculturalism the identities of the language groups are acknowledged by the state simultaneously guaranteeing the participation of each of the groups in the common public sphere (König 1999; Bartha, 2003; Androutsopoulos, 2014). Analysing the present tendencies, the minority languages lose ground and disappear much faster than ever during the history of mankind (SkutnabbKangas 1999; Krauss, 1998; Bartha, 2003; Fenyvesi, 2005). Certain languages become more and more important in point of numbers (world languages) for the detriment of the endangered languages. A great proportion of the minorities living in the bilingual situation created by social-economic-political constraints passes through language shift: in a shorter or longer period of time they take over the language of the majority abandoning their original language (Gal, 1979; Bartha, 1999 és 2003; Androutsopoulos, 2014). From the point of the view of the language those bilingual minority speaking communities are endangered where the original language is not delivered by the parents to their descendants (Grenoble-Whaley, 1998; Bartha, 2003; Henry et al, 2017).

There are several stages and reasons for the threat of languages which are in majority not lingual but such external, historical, social, economic, political or cultural factors which shape the life of a certain group and its language using environment (Kloss, 1966; Haugen, 1972; Bartha, 1999 és 2003; Borbély, 2001; Fenyvesi, 2005; Androutsopoulos, 2014; Henry et al, 2017). The real threat of a language starts when its demographic, social and political environment changes in a way that by losing its actual communicative value the related roles and values become exclusively symbolic (Bartha, 2003, 1).

The recent researches emphasize that the loyalty of those who speak minority languages to their language lasts only until the economic and social circumstances make it possible (Dorian, 1981; Edwards, 1985; Bartha, 2003). Retaining or giving up a language and the social, economic succeeding are strongly related, however the direct 
compliance with each other is by all means simplifying, because these processes actuating with or against other affective factors can be reversed as well (Bartha, 2003, 1.). As far as we highlight the fact that due to globalisation the English language knowledge became obvious in an increasing geographical space and professional fields, the symbolic market value of the English language is decreasing and the high-level knowledge of other - not only world - languages, in other words the bi- or multilingualism, has been valorised (Grin 1999; Skutnabb-Kangas 2000; Bartha, 2003).

Based on the researches of the UNESCO and other organisations the Hungarian language is not on the list of endangered languages. Nevertheless, if we investigate it the threat locally (to a country or a region) we can conclude much different consequences. In the case of the Hungarian minority there are significant differences by landscapes, settlement types or different groups showing a strong correlation with the geographical allocation of the language minority, whether it is concentrated, scattered or diaspora-like and with the local ratio of the two, differing language groups as well (Bartha, 2003, 2.). In this topic there is no understanding among the researchers (Szépe, 1999; Lanstyák et al., 1999) but they agree that in the countries neighbouring with Hungary - due to the different factors - the Hungarian language is endangered, since on the one hand the bilingualism of the Hungarian communities in the Carpathian Basin typically shows stability, but on the other hand we can experience certain phases of language shift even in the homogenous blocks (Bartha, 2003). It results in the decrease of the factual and symbolic functions of the Hungarian language where as a consequence the number of the people speaking the language decrease and in parallel the majority language will gather ground. These processes can be seen in the scope of the Hungarians living in ethnically mixed areas (Szépe, 1999; Péntek, 2000; Lanstyák, 2000; Sándor 2000, Bartha 200).

The counterpoint of language shift is language preservation getting in the focus of research from the 1960s (Fishmann, 1966, 424.) at the same time with the appearance of the intentions urging the sustaining of the culture and language of bilingual communities (Borbély, 2001). Language shift and language preservation are reverse processes, nevertheless they are present - but with varying degrees - at the same time in certain communities, since both phenomena are connected with the social and cultural changes and the relations among the groups (Fishmann, 1966; Amastae, 1982; Borbély, 2001).

\section{THE HISTORICAL AND PRESENT ANALYSIS AND EVALUATION OF THE IDENTITY PRESERVING ACTIVITY OF THE HUNGARIAN SHOOLS IN THE DIASPORA}

\subsection{THE PRESERVATION OF THE HUNGARIAN IDENTITY IN AUSTRALIA: THE HISTORY AND PRESENT OF LANGUAGE EDUCATION IN THE HUNGARIAN COMMUNITY SCHOOL, ADELAIDE}

In Australia the number of the Hungarian diaspora is quite significant apparently among $67000-68000$ persons. They primarily live in Sydney, Melbourne and Adelaide and in their agglomeration (Gazsó, 2016). The migration to the continent started later then to America, in greater number only from the middle of the 1950s (Kuncz, 1997). In Australia after the $2^{\text {nd }}$ World War the Hungarian refugees had the demand and the possibility as well to educate their children in their mother language.

The Hungarian Community School in Adelaide is a so-called ethnic school which are typically non-profit language and cultural centres accessible for everyone. The altogether 100 ethnic schools in Southern Australia educate in 49 languages after school in the weekends or in the evenings. It is an expectation that the schools should provide at least two hours per week for the students with the aim of language learning, sustaining the different cultures of the Australian communities and facilitating the cultural understanding and harmony. The students are usually school-aged children but numerous ethnic schools are educating pre-school children or adults (Department of the Premier and Cabinet, 2017).

The Hungarian Community School in Adelaide was founded by Dr. Ákosné Nagy in 1958 with the aim of preserving the Hungarian identity by teaching Hungarian culture, folk dance and language for the 1956 refugee families. At this time the great proportion of the students where the children of the immigrants so typically the 615-year-olds went to school who were around 30-35 persons altogether. In the 1990s the leadership of the school was received by János Herendi who were later followed by Mária Nagy, Annamária Bánházi and Ilona Lelkes. At this time based on the opportunity by the Australian educational regulation's students practising for high school graduation also joined the school prepped by Sebestyén Maglai and Annamária Bánházi (Szabó, 2017; Palotai - Szabó - Jarjabka, 2017). The present number of the students is demonstrated by the following table (Table 1.). 
Table 1: The number of the students of the Hungarian Community School in Adelaide between 2001-2016 (persons)

\begin{tabular}{|c|c|c|c|c|c|c|}
\hline Year & $\begin{array}{l}\text { Pre-school } \\
\text { students }\end{array}$ & $\begin{array}{l}\text { Prep school } \\
\text { students }\end{array}$ & $\begin{array}{c}\text { Elementary school } \\
\text { students }\end{array}$ & $\begin{array}{l}\text { Secondary school } \\
\text { students }\end{array}$ & $\begin{array}{c}\text { Adult } \\
\mathrm{S}\end{array}$ & $\begin{array}{l}\text { Altogeth } \\
\text { er }\end{array}$ \\
\hline 2001 & 0 & 0 & 21 & 4 & 1 & 26 \\
\hline 2002 & 0 & 0 & 18 & 4 & 0 & 22 \\
\hline 2003 & 0 & 0 & 13 & 10 & 10 & 33 \\
\hline 2004 & 1 & 0 & 9 & 6 & 7 & 23 \\
\hline 2005 & 1 & 0 & 15 & 11 & 3 & 30 \\
\hline 2006 & 4 & 1 & 15 & 8 & 0 & 28 \\
\hline 2007 & 3 & 2 & 9 & 0 & 0 & 14 \\
\hline 2008 & 0 & 2 & 5 & 5 & 0 & 12 \\
\hline 2009 & 0 & 4 & 5 & 1 & 0 & 10 \\
\hline 2010 & 0 & 5 & 5 & 3 & 0 & 13 \\
\hline 2011 & 3 & 0 & 12 & 5 & 0 & 20 \\
\hline 2012 & 3 & 2 & 21 & 1 & 15 & 42 \\
\hline 2013 & 5 & 2 & 12 & 2 & 10 & 31 \\
\hline 2014 & 5 & 3 & 13 & 4 & 15 & 40 \\
\hline 2015 & 3 & 0 & 10 & 7 & 0 & 20 \\
\hline 2016 & 0 & 0 & 2 & 15 & 3 & 20 \\
\hline $\begin{array}{l}\text { Altogeth } \\
\text { er }\end{array}$ & 28 & 21 & 185 & 80 & 64 & 384 \\
\hline Ratio & $7,3 \%$ & $5,5 \%$ & $48,2 \%$ & $20,8 \%$ & $\begin{array}{c}16,7 \\
\%\end{array}$ & $100 \%$ \\
\hline
\end{tabular}

Source: Palotai J. - Szabó Á. - Jarjabka Á. (2017): The identity preserving efforts of the Hungarian diaspora in Australia through the example of the Hungarian Community School in Adelaide, Civil Szemle vol. 14. no. 3. pp. 96.

The number of the elementary school students is the highest with more than $50 \%$ share, which suggests that the parents start to more deeply familiarize the children with their ancestry. The ratio of the preschool students $(7,3 \%)$ and the prep school students $(5,5 \%)$ are smaller whose number stagnated in the researched period most probably meaning that it derives from the assimilation and the different ethnic marriages. It is worth examining the number of the students learning Hungarian from 2011 since on $26^{\text {th }}$ May, 2010 the Government of Hungary accepted the modification of the $1993 \mathrm{LV}$. act introducing the simple nationalization procedure. Its main point is that the crossborder Hungarians should not settle down in Hungary and should not make a citizenship examination either but the knowledge of the Hungarian language is needed (The Embassy of Hungary, 2014). Due to the judicial measures from 2011 the number of those who intend to learn Hungarian grew significantly. The number of the students at the adult classes also grew significantly, out of which $67 \%$ are learning from 2011 (see Table 1.). Such increase could be seen in the case of the preschool students out of which $68 \%$ started to learn Hungarian after the introduction of the 2010 simplified citizenship act. So, it is obvious that the modification of the act had a positive impact on the Hungarian language learning habits of the Hungarian diaspora in the Southern Australian region (Palotai - Szabó - Jarjabka, 2017).

There are 4 schools with accreditation of the Australian Government, the state language schools in Canberra, Sydney, Melbourne and the Hungarian Community School in Adelaide which is the only community school where the teachers are working $100 \%$ as volunteers. The students with Hungarian origins living in other states learning Hungarian language cannot properly prepare themselves and not even register for the graduation, out of which only Perth is an exception where students can register for the exam as private students as well.

According to the Australian regulations, on the national level in order to sustain the opportunity a minimum of 15 students should register for the exam which causes a serious problem for the Hungarian schools. Ágnes Szabó is investigating on this problem determining the following statements: It is understandable that the local schools have adequate number of students but when they got to the graduation, they will not check in for the language challenge. It is also a problem that the Saturday morning timetable of the weekend school's coma up against the sports 
programmes or in the other afternoon students' programs. A further phenomenon is that in such cities where Hungarians are living in greater numbers the students apply for the Hungarian language graduation only in a few numbers. The Hungarian Community School in Adelaide also had to face with these problems, since in order to survive in 2010 they had to find such Hungarians who can successfully graduate. In that year they managed to find 5 students but this was not enough for the requested 15 students on the national level (Palotai - Szabó - Jarjabka, 2017, 98.).

As a result of a strong marketing campaign, in 20115 adult students applied for graduation in Adelaide and the total number of graduating students increased to 27 in the country. Based on this we can conclude that it is not about disinterest and further on that a certain layer of the Hungarian originated adults - who could not graduate earlier in Hungarian language - would kindly challenge their knowledge. Unfortunately, they could only take advantage of this opportunity only for a short period of time since in 2012 the Government of the Province of South Australia maximised the age of the graduating students in 21 years. The consequence of this regulation was detected in the number of applicants since in 2012 and in 2013 it was only 1-1 students graduating in Adelaide (Palotai - Szabó Jarjabka, 2017).

Partly trying to fence off these impacts the AMPE, the Hungarian Teachers Association of Australia was established in 2013, representing themselves already in 2015 at the Diaspora Council. The membership thought that it would be worth introducing the e-learning methods besides the traditional didactic and pedagogical methods. In 2014 the Hungarian Community School in Adelaide tried with their own students the opportunity of learning through internet, causing an increase in the number of student one year after its introduction in 2015 illustrated by Table 2. (Palotai - Szabó - Jarjabka, 2017).

From 2015 the school had already 7 secondary school students who were specifically prepared for graduation. Out of the enrolled students 2 were from Queensland and 1 from Western Australia where the students were educated though Skype in cooperation with the Szivárvány (Rainbow) School educating elementary school students on the Gold Coast. In the following years the scholars accredited by the Kőrösi Csoma Sándor program to Adelaide were also involved in the education. In 2016 the school already had 15 students preparing for graduation out of which 10 persons participated from other provinces through online education. In 2016, besides the weekly 1 hour provided by the community school, the Hungarian as foreign language students of the Károli Gáspár University of the Reformed Church taught the students of the school with the management of Dr. Orsolya Nádor and with the help of Skype. In 201710 online students were enrolled from other provinces and further on the school is having 6 students presently as well, so it has been confirmed that the adequate communication and education methods can be successful. Lastly the 2014 initiative of the Community School has to be mentioned due to which the ones applying for graduation could learn as exchange students in the Reformed Grammar School of Kiskunhalas and from autumn, 2017 in the István Bibó Grammar School as well. So, in 20143 students from Melbourne, in 20151 from Melbourne and 1 from Adelaide, in 20161 from Adelaide and in 20171 from Adelaide and 2 from Melbourne arrived to Kiskunhalas to develop their Hungarian language knowledge within the framework of the programme (Szabó, 2017).

Table 2: The composition of the students preparing for graduation and who graduated in the Hungarian Community School in Adelaide (person)

\begin{tabular}{|c|c|c|c|c|c|c|}
\hline & Provinces & 2015 & 2016 & 2017 & $2018^{1}$ & Total \\
\hline Enrolled students & South Australia & 4 & 5 & 6 & 2 & 17 \\
\cline { 2 - 7 } & Queensland & 2 & 2 & 2 & 2 & 8 \\
\cline { 2 - 7 } & Western Australia & 1 & 1 & 1 & 2 & 5 \\
\cline { 2 - 7 } & Victoria & 0 & 1 & 1 & 0 & 2 \\
\cline { 2 - 7 } & Northern Territory & 0 & 1 & 1 & 0 & 2 \\
\cline { 2 - 7 } & New South Wales & 0 & 5 & 5 & 4 & 14 \\
\hline
\end{tabular}

1The number of enrolled students at the start of the year in January will probably be higher.

Source: Palotai J. - Szabó Á. - Jarjabka Á. (2017): The identity preserving efforts of the Hungarian diaspora in Australia through the example of the Hungarian Community School in Adelaide, Civil Szemle vol. 14. no. 3. pp. 99. 
In the functioning of the organisation the financial maintenance of the infrastructure means a challenge together with the assurance of the volunteers with adequate electronic educational competences and the initiation of the native language environment. The upper mentioned network cooperation provides a support for these problems. The language education supported with electronic forms lead to the formation of virtual communities which can significantly contribute to the preservation of identity in the diaspora even in an isolated situation. At the same time sustaining the evolved relations become a continuous activity with the help of the online, smart devices.

The adult education and the new education methods, such as e-learning also have a role in the preservation of the double identity (Australian Hungarian) and the Hungarian identity as well. This latter is of great importance because of the great distances in Australia nevertheless the different regulations on education in the provinces and the peculiar regulations of the schools make this type of teaching more difficult. Only the learning of the Hungarian language is less incentive so in adult education getting the Hungarian citizenship is an essential aspect. In the case of the young generation besides community building (such as scouts) the increase of the value of the graduation is a motivating factor as well that it takes out some of the subjects and also provides extra points at the university prelim (Palotai - Szabó - Jarjabka, 2017).

The attitude of the new immigrants towards Hungarian identity is completely different from the idealised mother country image of the $2^{\text {nd }}$ and $3^{\text {rd }}$ generation Hungarians and even in some cases it is reverse. Namely we cannot forget that a certain part of the Hungarian immigrants chose Australia because of existential pressure so they intend to adapt themselves, to assimilate, create financial safety and would like to improve their English language knowledge. All this is frequently carried out by impairing the energies towards the attendance of the Hungarian identity. So, time and opportunity is needed for these families to find again their Hungarian origins and the community. Namely for the children of those families who immigrated to Australia in the near past a completely different educational programme should be composed since their majority speak Hungarian and so the focus should be on writing, reading and the extension of their vocabulary.

\subsection{THE PRESERVATION OF THE HUNGARIAN IDENTITY IN THE UNITED STATES OF AMERICA: THE HISTORY AND PRESENT OF LANGUAGE EDUCATION IN CLEVELAND}

The North American community in Cleveland experienced a different way in the approach to the preservation of the Hungarian identity. The first Hungarian school in Cleveland was opened in 1893 operated by the Szent Erzsébet (Saint Elizabeth) Hungarian Catholic Church founded in 1892. In the first year the education took place with 1 class and 1 teacher. The school was continuously expanded so by 1900 more than 350 students were educated in English with the help of the 2 nuns from the Orsolya Order while the Hungarian language and bible classes were taught by the parish priest (Fejős, 1991, 7.). The number of students showed a continuous increase also due to that between 1871 and 1913 primarily because of economic-existential reasons nearly 2 million Hungarian citizens left the mother country to overseas (Gazsó, 2016, 14.) and as a consequence by 1919 the number of enrolled students reach 1114 (Papp, 1981, 188.).

The Szent Imre (Saint Emeric) Catholic Church was opened in 1905 in the western parts of the city also joining the education of the Hungarian diaspora. The parish priest and the nuns sent from Hungary taught Hungarian language, history and geography approximately for 150 students (Gárdosi, 2014). The Calvinistic Bishopric built its Hungarian church on the East side in 1894. By 1919 the Saturday and summer holiday Hungarian language and bible classes education were generally visited by 600 students. Besides this several other congregations (Greek Catholic, Hungarian Evangelical Congregation, Jewish Church) provided Hungarian language education in the settlement (Papp, 1981; Fejős 1991; Gárdosi, 2014). There was no opportunity but it was a definite need of the Hungarian immigrants to maintain such Hungarian schools which are equal to the state schools and independent from the church schools on the long. This problem was solved with an interim solution in a way that weekend and holiday education was organised the members of the diaspora with the help of the churches. The Hungarian Government also pushed this form of education and further on also that during the building of new churches adequate school buildings should be built by the different churches as well (Fejős 1991; Gárdosi 2014).

In order to expand education, the Hungarian Government developed a uniform curriculum for the schools which was elaborated by the Julián Association (established in 1904 by the initiation of Count Béla Széchenyi). The curriculum specified what kind of material and topics should be dealt with and provided a thorough pedagogical guideline due to which the Hungarians living in the diaspora received the following curriculum: Hungarian language 
(oral expression, comprehension practice, reading, writing, grammar), the history of the Hungarian nation, constitution studies, the geography of Hungary, singing (folk songs, religious songs). The tutors had to use the domestic elementary school text books and reference books (Fejős 1991, 12.; Gárdosi 2014). But the Hungarian diaspora in Cleveland quickly gave voice to that there is a greater need for text books elaborated specifically for the American Hungarian schools, since the $2^{\text {nd }}$ and $3^{\text {rd }}$ generation Hungarians were attached differently to the mother country then the Hungarian society in general (Fejős 1991; Gárdosi 2014).

The Hungarian migration regained strength in the 1940s where during not even 2 decades hundreds of thousands of Hungarians left the country in 3 migration waves altering in time and characteristics. The first was constituted by those soldiers, prisoners of war and deportees who got abroad during the war and did not intend to come back home and those who escaped from the Soviet army. The $2^{\text {nd }}$ wave was during the years before the state socialism composed by the representatives and supporters of the democratic endeavours and the $3^{\text {rd }}$ was evoked by the breaking down of the 1956 revolution (Gazsó, 2016,19.). A significant part of the migration towards the United States of America was constituted by the "dipik" (in Hungarian), the displaced persons. Hungary belonged to the biased countries, the former enemies, together with Italy, Romania and Bulgaria (ex enemy DPs) from where more than 360000 persons migrated to the USA (Gazsó, 2016). After the 1956 revolution around 200000 persons left Hungary (who are called 56er Hungarians in the diaspora), out of which a significant part left the country between 1956 and 1957. Most of them moved the USA with an approximate number of 40000 persons (Gazsó, 2016).

Hungarians arrived to the State of Ohio and within that to Cleveland in significant numbers meaning that Hungarian education and schools will further be needed and even their expansion. Due to this the Hungarian Central Textbook Committee was formed in 1958 taking care of the maintenance of 2 Hungarian schools in Cleveland. So with the leadership of János Palasics on the eastern part and the leadership of Fréda B. Kovács on the western side adult education was carried out in 2 different parts of the city. On a weekly basis Hungarian language courses were organised for $2^{\text {nd }}$ and $3^{\text {rd }}$ generation young students already hardly speaking Hungarian (Somogyi, 1989). In 1962 the Sándor Remenyik Hungarian Language School of the Cleveland Warriors of Independence Circle was formed in the scout home in the eastern side where during 7 years an average of 60-70 students learned Hungarian. In 1969 the school in the Buckeye district (the Hungarian district in Cleveland in the first half of the 1900s) was reorganised getting the new name, Géza Gárdonyi Hungarian School.

In the beginning the centre for the education was the scout home, than later the Harvey Rice Library and the Evangelical church. Besides this, for the initiative of the Saint Margaret (Szent Margit) Roman Catholic parish, another Hungarian school was organised where language education was arranged on Sunday mornings. Later on the education was complemented by the lecture series of Hungarian studies by Professor Ferenc Somogyi (Szentkirályi, 2013; Gárdosi, 2014).

In 1958 the Cleveland Hungarian School was formed under the management of Gábor Papp senior. The school was primarily established to educate Hungarian language to the immigrants coming after 1945 and in 1956 . The establishment of the school was and still is strongly tied with the scout movement. The aim of its establishment was to involve the Hungarian diaspora of Cleveland in the work of the scouts and to continue it, and also to rescue the Hungarian Christian national consciousness, preserve the Hungarian language and culture for the up and coming generations (Szentkirályi, 2008). In the beginning the majority of the students were coming from Hungary, so there was no problem with their language knowledge that is why they learnt materials connected to scout training. Nevertheless, as years went by the language background of the Hungarians living in the diaspora changed inducing the change in the content of the curriculum as well (Németh, 2008; Gárdosi, 2014). The school started its operation in a private house only with 36 students. During the education the students learnt basic knowledge on the Hungarian language and on the Hungarians. Later the place of education was moved to the scout home, than to the Greek Catholic parish, than to the Evangelical church in the west side which was operating at the same place with the Calvinist Church.

In the first 20 years of the Hungarian School more than 600 students learnt in Hungarian (Somogyi, 1989, 1011; Gárdosi, 2014). The education was reformed by Ödön Szentkirályi who became director in 1988 and who revised and systematised the curriculum and teaching system of the school. The curriculum embedded the scoutmaster and adjutant education as well providing help in the progress of the scouts and the school adapted the teaching material of the scout manager training as well. They also intended to teach the geography and history of Hungary from a more global aspect (Tálas, 2015).

Apparently, the Hungarian education is taking place on Monday evenings in the lecture rooms of the Szent Imre Catholic Church and the scout house with the management of Judit Szentkirályi both for children and adults. The 
curriculum is complemented with the education of the Friday night scout meetings and the Tuesday night Regös folk dance group (Gárdosi, 2014). The school is maintained by the contributions of the parents and the teachers are volunteers. The teachers are scouts, local Cleveland diaspora members, Hungarian scholars of the Körösi Csoma Sándor program and Fulbright and the priest of the Szent Imre Catholic Church. Nor pedagogical, neither teacher qualification is needed for the education (Gárdosi, 2014).

In the 2017-2018 study year of the Hungarian School education is carried out in 11 groups, in 3 nursery school groups, 7 school classes and scoutmaster courses, and 1 adult group, all with a separate tutor. Children between 4-6 years are attending the 3 nursery school groups (A, B and Basic). In group A the 4-5 years old children learn games, counting-out rhymes, says and songs in Hungarian, watch cartoons in Hungarian and also use colouring booklets and cutting books. Group B educates 5-6 years old children using similar topics and methods complemented with learning the ABC. At the end of the year an evaluation is made about each child. The teaching of the nursery school groups sometimes needs English explanations as well, but the teachers aim to use permanently Hungarian. The Basic group is carrying out the Hungarian language teaching of those children who do not speak Hungarian at all avoiding the problem that there are different levels of language knowledge among the children (Gárdosi 2014, Magyar Iskola Cleveland, 2017).

After graduating the $7^{\text {th }}$ year, the students can attend the scoutmaster course which is organised by the school together with the scouts. During the course the 13-14-year-old students already deepen their knowledge with literature, history and geography with the help of the textbook and exercise book published by the Foreign Hungarian Scout Association (FHSA). Besides this, similar to the classes, the students have to learn poems here as well (e.g., Elemérné Papp Váry: Hitvallás, Sándor Reményik: Az ige, László Mécs: A pisztrángok példája). At the end of the year the students make exams complied by the FHSA. The successful students will receive the Scout manager rank at their scout groups (Szentkirályi 2008., Gárdosi 2014).

Since 2002 the teaching of Hungarian as a foreign language teaching is also carried out in the Cleveland Hungarian School where typically adults with Hungarian origin are taking part. In the beginning they tried to use the textbook entitled "Halló, itt Magyarország" but according to the experiences the book presented difficulties for the students, since it is only in Hungarian lacking English explanations, so the tutors used their own materials. For the beginners the greatest problem was pronunciation and spelling (Gárdosi 2014).

It is important to highlight that besides the training in Monday at the end of the school year the Cleveland Hungarian School organises summer camps as well which is an organic part of the propagation of Hungarian language and culture in the USA. The first school camp was organised by the FHSA in July, 1968 in the Sándor Sík Scout Park, Fillmore. At present the majority of the campers are the students of the Cleveland Hungarian School and the Hungarian School. The camp is similar to the scout camps, nevertheless being or having been a scout is not a precondition for the attendance. During the camping the children are learning by their age groups and Hungarian language knowledge Hungarian literature, grammar, history and geography, while in the afternoon they can participate in craftsman occupations, singing folk songs, doing sports and folk dances. The camps are thematically organised around one story from the classics of Hungarian literature or historical events (Gárdosi 2014).

During the field work research the authors saw that the leaders, tutors, students and parents, besides language teaching, paid much attention and energies to fulfil such a comprehensive identity preserving activity as possible. As a tool for language learning they learn numerous Hungarian poems, and during the Hungarian national holidays the students together with the scouts prepare themselves with programmes for the Hungarian community. The Hungarian School enjoys good relations with several local Hungarian organisations (Hungarian churches, scouts, folk dance groups etc.) with whom they can make the needs for identity preservation of the local Hungarians complete.

\subsection{THE PRESERVATION OF THE HUNGARIAN IDENTITY IN THE REPUBLIC OF SOUTH AFRICA: THE HISTORY AND PRESENT OF LANGUAGE EDUCATION OF THE SOUTH AFRICAN HUNGARIAN ASSOCIATION}

The Hungarian community living in the Republic of South Africa is smaller than the other diasporas altogether with some 4000 persons.

The Hungarian Alliance of South Africa is having a more than 60 years old history established in 1957. They formulated as a primary role to sustain and further pass on the Hungarian identity. During our interviews it clearly 
turned out that the determining persons of the South African community and language education highlighted the importance of language teaching and especially getting to know Hungarian language and literature and history. They organise reading nights focusing on says and Hungarian folk tales for the children and on classic and modern literature for the elderly ones. Their mission is to preserve the Hungarian language, culture and values and their transmitting from generation to generation, the sustaining of Hungarian memorial occasions and festivals, the preservation of gastronomy and folk customs and the preservation and continuous development of the Magyar Tanya, the location where all these programs are taking place.

The Magyar Tanya provides the place for the semi organised Hungarian language education as well. The education is less organised then at the other analysed schools and it takes place in a less developed institutional framework as well, nevertheless it is important to mention that the motivation of the students is really high to learn and know the Hungarian language. This motivation is personal, in all cases the students have Hungarian roots or Hungarian consorts. The language is taught by a mandatory language teacher once in a week for 45 minutes in smaller groups with 8-10 persons. The number of these groups is intensely changing even on a week by week basis. The education and the courses are open and free for everyone.

We experience that the scientific analysis of the South African language education is extremely difficult since we can receive only subjective information and also as we mentioned the education is not so organised, there is no official outcome and the main motivation is mostly not the acquisition of the Hungarian citizenship or the continuation of the higher-level education in some Hungarian universities. The exception is the intensive Hungarian course organised in the summer time for the students who wish to go on to university in Hungary where nearly 100 students took part. Based on the above mentioned it is hard to compare the activity of the South African Hungarian language education with exact statistics with the other schools of the diaspora.

\subsection{THE COMPARISON OF THE LANGUAGE EDUCATION IN ADELAIDE, CLEVELAND AND JOHANNESBURG}

Comparison of the schools we present is a difficult task, as they are clearly different from each other, but their profile is same, so along it we use that in the analyzation. There is a common aim for the language teaching of the three analysed, organised institutions: the preservation of the Hungarian identity and the tradition and identity preservation of the Hungarian descendant generations. Nevertheless, the methodology is significantly different from each other both concerning the teaching material or the didactic methods. Table 3. illustrates and covers these differences where the Hungarian schools were compared with each other based on several aspects.

Table 3: The comparison of the schools in Adelaide, Cleveland and South Africa

\begin{tabular}{|c|c|c|c|}
\hline & Adelaide Community School & Cleveland Hungarian School & $\begin{array}{c}\text { Hungarian Alliance } \\
\text { of South Africa }\end{array}$ \\
\hline Teachers & volunteer & volunteer & deputy teacher \\
\hline $\begin{array}{l}\text { School age } \\
\text { groups }\end{array}$ & all age groups are present & $\begin{array}{c}\text { from the age of } 5 \text { to } 14-15 \\
\text { years and also adult } \\
\text { education }\end{array}$ & $\begin{array}{l}\text { all age groups are } \\
\text { present }\end{array}$ \\
\hline Motivation & $\begin{array}{c}\text { identity preserving, acquisition of the } \\
\text { Hungarian citizenship }\end{array}$ & identity preserving & $\begin{array}{l}\text { preservation and } \\
\text { passing on the } \\
\text { Hungarian identity, } \\
\text { folk customs }\end{array}$ \\
\hline $\begin{array}{l}\text { Methodology of } \\
\text { the education }\end{array}$ & $\begin{array}{c}\text { own materials, textbook preparing for } \\
\text { the Australian Hungarian graduation, } \\
\text { education through Skype }\end{array}$ & $\begin{array}{l}\text { textbooks of the Balassi } \\
\text { Institute, textbook of the } \\
\text { scouts, learning poems }\end{array}$ & $\begin{array}{l}\text { own materials, } \\
\text { lecture notes of the } \\
\text { teachers }\end{array}$ \\
\hline $\begin{array}{l}\text { Partner } \\
\text { institutes }\end{array}$ & $\begin{array}{c}\text { University of Pécs, Kőrösi Csoma } \\
\text { Sándor program of the Hungarian } \\
\text { Government, Rákóczi Association, } \\
\text { Károli Gáspár University, Körösi Csoma } \\
\text { Sándor Cultural Circle, Ethnic School } \\
\text { Association }\end{array}$ & $\begin{array}{l}\text { Hungarian Scouts in } \\
\text { Cleveland, Hungarian } \\
\text { churches, Regös Folk Dance } \\
\text { Group, Foreign Hungarian } \\
\text { Scout Association, Balassi } \\
\text { Institute } \\
\end{array}$ & $\begin{array}{l}\text { Magyar Tanya, } \\
\text { Balassi Institute, } \\
\text { Rákóczi Association }\end{array}$ \\
\hline
\end{tabular}




\begin{tabular}{|c|c|c|c|}
\hline $\begin{array}{c}\text { Tradition } \\
\text { preserving } \\
\text { activity }\end{array}$ & $\begin{array}{c}\text { tradition preserving in festivities, } \\
\text { education of Hungarian cultural } \\
\text { knowledge }\end{array}$ & $\begin{array}{c}\text { tradition preserving on a } \\
\text { regular basis together with } \\
\text { the scouts, the churches and } \\
\text { the folk-dance group }\end{array}$ & $\begin{array}{c}\text { regular, all year long } \\
\text { folklore events and } \\
\text { programmes }\end{array}$ \\
\hline
\end{tabular}

Source: Palotai J. - Szabó Á. - Jarjabka Á. (2017): The identity preserving efforts of the Hungarian diaspora in Australia through the example of the Hungarian Community School in Adelaide, Civil Szemle vol. 14. no. 3. 99 p., data from the Cleveland Hungarian School and the Hungarian Alliance of South Africa, own editing

The beginning of the education activity in the 3 schools fundamentally differ from each other which can be explained by the different time periods of arriving as for instance to North America and Australia Hungarians arrived earlier so the preconditions of language education were also established earlier. The language education in Cleveland was effectuated and operated with the help of the church, the South African Hungarian School is actuated by the Magyar Tanya owned by the Hungarian Alliance of South Africa, while the school in Adelaide started as an initiation of private persons.

The Hungarian schools in Adelaide and in Cleveland were established in 1958 but it was an advantage for the city in Ohio that the education of the Hungarian language is present for 65 years there. We can see this advantage in the education materials, infrastructure and in the experiences as well. Despite of the fact that the Hungarian language education in South Africa was established together with establishment of the Hungarian organisation in 1957, according to its organisation and number it cannot be compared with the earlier mentioned institutes, nevertheless its value and justification is inevitable.

A significant part of the present Hungarian diaspora can be found in the American continent (Gazsó, 2016) so the school in Cleveland can take from a greater basis than the one in Adelaide. The Australian school established its online education by eliminating the quantity and spatial barriers with which they were able to increase the number of their students. In Cleveland the education is carried out in the physical building of the school besides which the school also tried online education in the latter years, which did not prove to be successful. It is because in the United States of America in those cities where there is a Hungarian community, characteristically Hungarian language education is present as well.

The education structure of the schools is also quite different from each other. In its education process the Adelaide Hungarian Community School covers all the age groups, while in Cleveland nursery school children, and school children are taught until the age of 13-14 together with adult education and in São Paulo mainly the adults avail themselves the language course education. Nevertheless, it is also important to mention that in Cleveland besides the school there are numerous Hungarian organisations which are also visited by the adults and where the use of Hungarian language is required and so they can develop their vocabulary and their language knowledge can be kept up as well.

Further on the outcome of the education also differs, since in Adelaide the main aim of the school (besides teaching Hungarian language) is that the students should get the Hungarian graduation established by the Australian state, while in Cleveland the major output is that the students should finish the scout manager course of the Foreign Hungarian Scout Association. In South Africa the Hungarian Alliance's the identity and culture preservation role and activity is significant.

\section{SUMMARY}

We can clearly see from our researches that the main aim of the analysed education institutions is the teaching of the Hungarian language for the newer generations of the Hungarian diaspora and so the strengthening and the preservation of the Hungarian identity can be achieved as well, however with different approaches, measures and methods. We can detect differences in the scope of the students as well which can be explained mainly by the number and size of the certain diaspora. Notwithstanding, all the investigated schools make huge efforts in order to sustain the teaching of the Hungarian language and so transmitting the Hungarian language, identity and traditions for the future generations.

As the conclusion of the research, we can state that the analysed Hungarian communities reach their objectives with different motivations and methods. The greatest recent problem, not only for the Hungarian but for every diaspora, is succession and transmitting. The language and the environmental impacts both affect the national 
culture and assimilation is in many cases inevitable. In our research the data providers formulated that they are in a lucky position since the need for the Hungarian language and culture worked out adequately among the younger members of the community as well.

The visualisation and attendance of the domestic culture cannot exist without an adequate infrastructural and organisational system. Our research proved that the analysed settlements are in a privileged situation since we can find organised Hungarian cultural institutions providing as many opportunities as possible for the preservation and transmitting of the culture of the mother country. Of course, the financial background is also needed for the management of these institutions. Establishing and sustaining financial safety is not a significant problem for these institutes, moreover together with the civilian and mother country support their financial security is assured.

As a further direction of our research, we would like to suggest that all the schools, institutions and organisations dealing with Hungarian culture should be organised in a cultural cluster creating a knowledge transfer among them, providing a chance to share the education material and methods and their further development as well. In this case we could experience a significant step forward in the exploitation of the teaching of Hungarian language and the preservation of Hungarian culture in the diaspora.

The Diaspora Project Network at the University of Pécs could be adequate to hang together these activities. Under the aegis of the university such Hungarian-Hungarian workshops (dealing with Hungarian language education) could be operated where best practices and further on common application activities and governmental cooperation could be presented and established in order to plan and sustain the future existence. A long-term subsistence strategy should be planned by the Hungarian institutions of the diaspora for this global Hungarian school network in order to successfully maintain and preserve the Hungarian culture and identity.

\section{SOURCES OF FUNDING}

This research received no specific grant from any funding agency in the public, commercial, or not-for-profit sectors.

\section{CONFLICT OF INTEREST}

The author have declared that no competing interests exist.

\section{ACKNOWLEDGMENT}

None.

\section{REFERENCES}

[1] Amastae, J. (1982): Language Shift and Maintenance in the lower Rio Grande Valley of Southern Texas. In: Florence Barkin - Elizabeth A. Brandt - Jacob Ornstein - Galicia (szerk.) Bilingualism and Language Contact: Spanish, English, and Native American Languages. New York - London: Teachers College Press, Columbia University, 320, pp. 261-277.

[2] Androutsopoulos, J. (szerk.) (2014): Mediatization and sociolinguistic change. Berlin: Walter de Gruyter GmbH \& Co KG., vol. 36., 557 p.

[3] Bartha Cs. (2003): A kisebbségi nyelvek megőrzésének lehetőségei és oktatása. Letöltve: http://real.mtak.hu/13812/1/kimenet.pdf 2018. március 16. 9 p.

[4] Bartha Cs. (2005): A kétnyelvűség alapkérdései: Beszélők és közösségek. Budapest, Nemzeti Tankönyvkiadó. $268 \mathrm{p}$.

[5] Borbély A. (2001): Nyelvcsere. Budapest, MTA Nyelvtudományi Intézet. 305 p.

[6] Borbély, A. (2001): A nyelvcsere folyamata és kutatása. Nyelvtudományi Közlemények 98. kötet. pp. 193-215.

[7] Csapó, J. - Trócsányi A. (2007): Sustainability and Tourism in Pécs. Grazer Schriften der Geographie und Raumforschung. Contributions to the topic INTERREG IIIC Project „Ökoprofit International”. Graz, 2006 pp. 143-150 
Viktor Wetzl, and Jenő Palotai

[8] Department of the Premier and Cabinet (2017): Ethnic schools Forrás: https://www.sa.gov.au/topics/education-and-learning/schools/choosing-a-school/ethnic-schools 2017. december 14.

[9] Dorian, N. C. (1981): Language Death. The Life Cycle of a Scottish Gaelic Dialect. Philadelphia: University of Pennsylvania Press. 206 p.

[10] Edwards, J. (1985: Language, Society and Identity. Oxford: Basil Blackwell. 256 p.

[11] Feischmidt M. (2007): A megalapozott elmélet. In: Kovács Éva (szerk.) Közösségtanulmányok. Módszertani jegyzet. PTE BTK Kommunikáció és Médiatudományi Tanszék. Pécs-Budapest: Néprajzi Múzeum, REGIO könyvek, pp. 234- 242.

[12] Fejős Z. (1991): Az anyanyelvi oktatástól az etnikus kultúra átörökítéséig. (Magyar iskolaügy Amerikában 1890 és 1940 között). Budapest: Magyar Tudományos Akadémia Társadalomtudományi Kutató Központ Kisebbségkutató Intézet, $184, \quad$ pp. $\quad 7-40 . \quad$ Forrás: http://kisebbsegkutato.tk.mta.hu/uploads/files/olvasoszoba/magyarsagkutatoevkonyv/evkonyv1990_91.p df 2017. december 22.

[13] Fenyvesi, A. szerk. (2005): Hungarian language contact outside Hungary: Studies on Hungarian as a minority language. Amszterdam: John Benjamins Publishing, vol. 20, 424 p.

[14] Fishman, J. A. (1966): Language loyalty in the United States: The maintenance and perpetuation of non-English mother tongues by American ethnic and religious groups. Mouton, The Hague. 478 p.

[15] Gal, S. (1979): Language shift: Social Determinants of Linguistic Change in Bilingual Austria. New York-San Francisco-London, Academic Press. 213 p.

[16] Gal, S. (1991): Mi a nyelvcsere és hogyan történik? Regio - Kisebbségtudományi Szemle 2. évf. 1. sz. pp. 6676.

[17] Gárdosi R. (2014): A clevelandi magyar nyelvoktatás múltja és jelene. pp. 58-67. Forrás: http://epa.oszk.hu/01400/01467/00012/pdf/EPA01467_thl2_2014_2_058-067.pdf 2017. december 22.

[18] Gazsó D. (2016): A magyar diaszpóra fejlődéstörténete. Kisebbségi Szemle 1. évf. 1. sz. pp. 9-35.

[19] Grenoble, L. - Whaley, L. szerk. (1998): Endangered Languages: Language Loss and Community Response. Cambridge, Cambridge University Press. 380 p.

[20] Grin, F. (1999): Market Forces, Language Spread and Linguistic Diversity. In: Kontra, M. et al. pp. 169-186.

[21] Grosjean, F. (1984): Life with Two Languages. An Introduction to Bilingualism. Harvard University Press. 384 p.

[22] Haugen, E. (1972): The stigmata of bilingualism. In: Dil, A. S. szerk. The Ecology of Language. Essays by Einar Haugen, Stanford, Stanford University Press. pp. 307-344.

[23] Henry, M.- Carroll, F. - Cunliffe, D. - Kop, R. (2017): Learning a minority language through authentic conversation using an online social learning method. Computer Assisted Language Learning. pp. 1-25.

[24] Jarjabka Á. (2012): Kultúramenedzselési ismeretek. Pécs: Carbocomp Nyomda, 3. kiadás 279 p.

[25] Keményfi R. (2011): A nemzeti tér építésének lokális útjai, mitikus képzetei és térképi megjelenítésének formái. MTA Doktori értekezés, Debreceni Egyetem, 359 p.

[26] Kloss, H. (1966): German-American language maintenance efforts. In: Fishman, Joshua A. — Nihirny, V. — Hoffman, J. — Hayden, R. szerk. (1966): Language Loyalty in the United States. The Hague, Mouton. pp. 206252.

[27] König, M. (1999): Cultural Diversity and Language Policy. International Social Science Journal vol. 51. no. 161. pp. 401-408.

[28] Krauss, M. (1998): The scope of the language endangerment crisis and recent response to it. In: Matsumura, K. szerk. (1998): Studies in Endangered Languages. Tokyo: Hituzi Syobo. pp. 108-109.

[29] Kuncz E. (1998): Magyarok Ausztráliában. Budapest, Teleki László Alapítvány. 250 p.

[30] Kvale, S. (2005): Az interjú. Bevezetés a kvalitatív kutatás interjútechnikáiba. Budapest: Jószöveg Műhely, 288 p.

[31] Lanstyák I. - Simon Sz. - Szabómihály G. (1999): Nyelvpolitika a kisebbségi oktatásban. Fórum Társadalomtudományi Szemle 1. évf. 1. sz. pp. 89-98.

[32] Lanstyák I. (2000): A magyar nyelv Szlovákiában. Budapest - Pozsony: Osiris-Kalligram-MTA Kisebbségkutató Műhely. 368 p. 
http://www.mfa.gov.hu/kulkepviselet/YU/hu/Konzuliinfo/tajekoztato_honositasi_eljarasrol.htm 2017. július 1.

[34] Németh Sz. (2008): Hétvégi magyar iskolák az USA-ban - 2008 (Interjú- és dokumentumelemzés). In: Papp Z. A. (szerk.) Beszédből világ. Elemzések, adatok amerikai magyarokról. Budapest: Magyar Külügyi Intézet, 431, pp. 266-300.

[35] Nora, P. (2003): Emlékezet és történelem között. Múlt és jövő, 14. évf., 4. sz., pp. 3-16.

[36] Palotai J. - Szabó Á. - Jarjabka Á. (2017): The identity preserving efforts of the Hungarian siaspora in Australia through the example of the Hungarian Community School in Adelaide. Civil Szemle 14. évf., 3. sz., pp. 87- 103.

[37] Papp, S. M. (1981): Hungarian Americans and Their Communities of Cleveland. Cleveland Ethnic Heritage Studies. Cleveland: Cleveland State University, $324 \mathrm{p}$.

[38] Péntek J. (2000): A nyelv ritkuló légköre. Kolozsvár: Komp-Press, 290 p.

[39] Sándor A. (2000): Anyanyelvhasználat és kétnyelvűség egy kisebbségi magyar beszélőközösségben, Kolonban. Pozsony: Kalligram, 173 p.

[40] Skutnabb-Kangas, T. (1999): Linguistic Diversity, Human Rights and the "Free" Market. In: Kontra, M. Phillipson, R. - Skutnabb-Kangas, T. - Várady, T. (1999): Language: A Right and a Resource. New York: Central European University Press, 329, pp. 187-222.

[41] Skutnabb-Kangas, T. (2000): Linguistic Genocide in Education — or Worldwide Diversity and Human Rights? New Jersey: Lawrence Erlbaum 824 p.

[42] Somogyi F. (szerk.) (1989): Emlékkönyv. Az Egyesült Magyar Alap húszévi működéséről 1968-1988. Cleveland, Ohio, $56 \mathrm{p}$.

[43] Szabó, Á. (2017): Hungarian Community School Adelaide. Forrás: The Ethnic Schools Association of South Australia Inc. http://admin.mailo.com.au/t/ViewEmail/r/D0D001E336FBC50F2540EF23F30FEDED/23EF4B1ABE29A4 B063B21DE8DA818551 2017. december 28.

[44] Szentkirályi E. (2013): Hungarians in Cleveland 1951-2001: Then and now. Doktori értekezés, Debreceni Egyetem, $179 \mathrm{p}$.

[45] Szentkirályi E. (szerk.) (2008): Clevelandben még élnek magyarok? Visszaemlékezések gyűjteménye. Cleveland: Cleveland Cserkész Regös Csoport, 175 p.

[46] Szépe Gy. (1999): The position of Hungarians in Romania and Slovakia in 1996. Nationalities Papers 27. évf., 1. sz., pp. 69-93.

[47] Tabouret-Keller, A. (1968): Sociological factors of language maintenance and shift: a methodological approach based on European and African examples. In: Fishman, Joshua A. - Ferguson, Charles A. - Das Gupta, J. (eds.), Language problems of Developing Nations. New York: John Wiley and Sons, Inc., 521, pp. 107-118.

[48] Tálas T. (2015): Szentkirályi Ödön bácsi mesél a Magyar Iskoláról. Forrás: Bocskai Rádió https://www.bocskairadio.org/szentkiralyi-odon-bacsi-mesel-a-magyar-iskolarol/ 2017. december 22.

[49] Taylor, P. J.-Flint, C. (2000): Political geography. Prentice Hall, 412 p.

[50] Universidade de São Paulo (2018): Az iskola belső anyaga

[51] Vers R.-Wetzl V.-Reményi P. 2017: A magyar kisebbségi kultúra és intézményei a Nyugat-Bácskában - Zombor és Kúla. In: Mediterrán és Balkán Fórum, 10 évf., 3. Szám, pp. 15-28. 